\title{
Through the International Looking Glass: Reflections from a Career in Global Education
}

\author{
Alan E. Wheeler \\ Rahul Kumar \\ Brock University
}

\begin{abstract}
Preamble
On the eve of his retirement, Dr. Alan Wheeler (AW) was interviewed by Rahul Kumar (RK). The interview focused on Professor Wheeler's international experience which spans over four decades and his assessment of how educational developments might unfold on the international scene, with the increased prominence of globalization.

Since 1964, Prof. Wheeler's teaching career has included long term postings in Tanzania (1967-72), Malaysia (1989-90), South and Central Asia, and Eastern Africa (1995-2000). A central theme in his work has been the exploration of ways in which Universities can function more effectively as "internationalizing agents."

Préambule

À la veille de sa retraite de l'enseignement à la Faculté des sciences de l'éducation à l'université Brock, le professeur Alan Wheeler (AW)
\end{abstract}

Professor Wheeler joined Brock University as a faculty member in 1977 and has maintained a strong interest and involvement in international and comparative education over the years.

Rahul Kumar received his formal education on three continents. He remains interested in similarities and differences of educational systems of various countries and devotes much of his attention to the forces that determine specific educational practice. Presently he is a doctoral student in the Joint Ph.D. program in Education, in Policy and Leadership stream. 
partage avec Rahul Kumar (RK) les points forts de son expérience internationale de quatre décennies et ses réflexions sur les prospectives de développement de l'éducation sur la scène internationale dans le contexte de globalisation envahissante. Depuis 1964, la carrière du docteur Wheeler a compris de longs séjours en Tanzanie (1967-72), en Malaisie (1989-90), en Centre-Asie et en Asie du Sud ainsi qu'en Afrique orientale (1995-2000). Il s'est penché surtout sur le rôle des universités en tant qu'agents d'internationalisation. L'article porte, entre autres, sur l'éducation des femmes, la pauvreté, la pandémie du SIDA en Afrique et l'influence équivoque de la technologie et de l'éducation eu égard aux problèmes sociaux.

In my conversation with Professor Wheeler, it was abundantly evident from his contemplative posture and reassuring tone, that he is passionate about this field of study. He entertained my questions seriously and his ponderings seemed as though he were taking me for a walk down memory lane. Just as easily he produced facts and figures to support his assertions. It was an educational experience for me.

In this interview, Professor Wheeler touched on numerous topics - the role of education of women, poverty and the AIDS pandemic in Africa, technology's dubious role in addressing social problems, and the role of education in curbing many of the disturbing trends in societies around the world. By covering such a vast terrain, Dr. Wheeler demonstrated how things are inextricably interrelated and why it is important for educators to remain optimistic and committed to the education of the underprivileged for it is through such efforts that the general conditions stand to improve. And yet, Dr. Wheeler would be the first to caution us to be on guard against not-so-chaste intentions that often operate under the surface of international ventures by higher educational institutions.

RK: It is a great pleasure to speak with you on a topic that is not only current and relevant in today's day and age, but one that you speak very passionately about. From where does this interest in international 
Through the International Looking Glass

education emerge?

AW: I'm not really sure, but feel my international roots must have been a combination of both my home environment and a strong case of wanderlust! Certainly much of it was influenced by my family environment. My father joined the Indian Medical Service as a young Canadian medical graduate from the University of Alberta in 1935 and, after a year's study in tropical medicine in England, served as a medical officer in various parts of pre-independence India. As you can appreciate, this was a rather adventurous thing to do at the time. I came along in Karachi, Pakistan shortly after, but unfortunately left as a 2-year-old so any recollection of my very early years were only acquired by looking at the family photos over the years. Perhaps the photos themselves were also part of the international roots?

Still, I've always had an innate interest in international studies and felt geographical area of the world that I have been able to see in my lifetime. I realize that one can always travel globally in a virtual sense, but I've tried to be more concerned with practice and so I have proactively sought out international positions over the years. Our travels to date have only served to further stimulate my wanderlust appetite. I say "our" travels because my wife Hilde has been an integral part of all my long term assignments, some 11 years in total, and without her support, my international career wouldn't have been possible, nor would it have been so enriched.

RK: Can you explain what you mean by International Education? Is it a discipline or a field of study, or ...?

AW: International Education, for me, is all-encompassing and refers to the totality of ways in which educational institutions, ideas, or practices of one's social or cultural group influence others. Hence, International Education addresses the significance and implications of a range of features, like literacy, equity, the role of education in international development, the persistence of colonial practices, teacher education, and so on, which hold meaning for all involved in the educative process. A heavy emphasis in my courses is placed on the role and function of education in the developing world context as a springboard 
for deliberations which are essentially global in nature. Comparative Education, which is really a subset of this international orientation, therefore becomes an especially important mirror of the values and priority that a particular nation places on education.

RK: Can you briefly describe the countries and international projects that you have been involved with?

AW: My overseas experience has mainly been acquired through a series of longer-term assignments interspersed with shorter consultancy positions. Collectively, I have educational work experience in a number of developing countries (Tanzania, Kenya, Uganda, Pakistan, India, Bangladesh, Nepal, Malaysia, Singapore, Somaliland, Thailand, Indonesia, Philippines, Egypt, Tajikistan, Kryghyzstan, and China) and have visited schools informally in others (Madagascar, Ethiopia, Turkey, Mexico, Nepal, and Sri Lanka). Remarkably, I've observed that classrooms the world over look and operate in a similar manner. This has always fascinated me and I suppose illustrates a type of educational "involution" whereby schools and educational systems continue to undergo "involution" rather than "revolution" through refinement and fine tuning of the original structure, namely the traditional classroom which is usually characterized by a high degree of teacher direction, one-way knowledge transmission, and an emphasis on rote learning. The result of the involution process is that there is often little real substantial change or innovation. For me, the intriguing question has been: What is it about the universal nature of classrooms that accounts for this resiliency?

The projects I have been associated with were mainly concerned about school improvement and raising the quality of teaching and learning in contexts where educational resources are often very limited. I feel that the teacher has a critical role to play in this change process, especially as it relates to accessibility of schooling for girls in rural areas where the problems are normally most acute. Substantial improvement in the quality of teaching and learning to occur requires a critical mass of like-minded professionals acting together over a realistic time period. The support of the School Head 
Through the International Looking Glass

is also a major determining factor in meaningful change and school improvement.

RK: What was your first educational experience abroad?

AW: It came about after several frustrating attempts to land an overseas teaching position, as most international appointments then required a minimum number of years of experience abroad. I say frustrating because after University graduation, we were both keen to travel but of course lacked the prerequisite experience and were continually told to "come back when you have acquired a minimum of five years experience." We argued that we should be allowed to qualify before we became encumbered with the normal restrictions of life i.e. family, mortgage, professional responsibilities, and the like. By this time, I had begun my science teaching career and Hilde was working in the local hospital. After one year they offered me the VicePrincipalship of the local high school and encouraged me to apply for the upcoming position of Principal of the new high school under construction. I could see the walls closing in and our international plans going out the window! Still, after some further experience under our belt, and several applications later, we were offered a position in Tanzania in 1967, which we immediately accepted. I laugh now because, once I hung up the phone we had to look in the atlas to find where we were going! Others must have had the same problem as our freight shipment was originally labelled for Tasmania before we discovered the error!

RK: It is often said that one's first experience leaves a lasting impression. Is this true for you? Can you share with us any influences that your African experience had on your work?

AW: Our first acculturation experience certainly was a formative one and has influenced our lives greatly ever since. I began to better appreciate the real significance of the adage, "Thinking Globally, Acting Locally" and can honestly say that not a day goes by that I don't draw on learning and experiences acquired in those five years in East Africa. On that note, I am deeply saddened by what has happened to Africa in general over the last three decades or so. 
RK: Can you expand on what you feel has taken place in Africa?

AW: To set the scene, over $80 \%$ of the world's six billion plus people reside in the developing world; collectively these nations make up less than twenty percent of the global wealth. This gross disparity between the "have" and "have not" countries of the world, the so-called Global Gap, manifests itself in many ways, but perhaps most dramatically in Africa. Aside from being the world's poorest continent and suffering from the HIV-AIDs pandemic which we hear so much about, the startling fact is that even if its economy were to continue to grow at the confident rate achieved in the 1990's, Africans would still have to wait until 2030 to achieve the income levels they had in the 1970s! Exclude Nigeria and the wait would last much longer.

The rapid technological and information-processing advancements that have taken place in the developed world only serve to exacerbate existing global disparities. Such advances have given rise to a new dimension of the Global Gap - that of the digital divide and the creation of the "Net Generation," the first generation of children to grow up in the digital era. The disturbing feature for Africans and others who reside in the developing world, which includes about $80 \%$ of the world's population, is the fact that the Global Gap is widening rather than closing. Digital technology undoubtedly is only one of many factors that contribute to the growing complexity and deepening disparities that exist in a period of pronounced globalization.

RK: It is argued by some that the digital revolution is contributing to this gap that you speak of and others insist that it is helping bridging it. Surely there is a happy medium.

AW: I see the role of technology as critical to closing the global disparity gap but recognize the complexity and magnitude of the problem. The reality remains that while information and communications technologies (ICTs) have an important role in meeting internationally-agreed development goals, one billion people in the world still don't even have access to a telephone. Further, it is estimated that around 800,000 villages, or 30 percent of all villages 
worldwide, are still without any type of connection. Hence it is clear that the development promise of science and technology remains largely unfulfilled for the poor of the world. There are many reasons for this and it is easy to point a finger: slow growth in the world economy, slow progress in reform among developing countries, and inadequate support from developed countries as mentioned earlier. For me, the message is abundantly clear: The goals of the Millennium Development Agenda are still achievable in most or possibly even all countries, but will require a dramatic acceleration and scaling up of action on many fronts, particularly in basic education, if information and communication technology is to play an active role in reducing the development and poverty gap.

RK: How do these global problems relate to education?
AW: The educational problems in the developed and less developed world differ markedly in both the massive scale and severity of the issues confronted. Less-developed countries for example, face massive general problems including basic literacy, which is nearly universal in the developed world but under $50 \%$ in many developing countries; far lower levels of completion of primary education; much higher attrition rates during and at the end of primary schooling; increased pressures caused by higher population growth rates; and more importantly, an average expenditure on schooling per student some 20 times lower than in the developed world. In virtually all respects, the material conditions of education in the developing world are far worse than in the developed world. The demographics are almost overwhelming and difficult to comprehend. There are more than 800 million illiterate adults in the world today, nearly 100 million primary-age children, and an even larger number of secondary-school- age students who are not even in school. Furthermore, millions of those who do attend school do not receive an education of a quality to help meet even their basic needs. Not to mention that the basic needs are changing in light of the rapidity of globalization forces and technological advancements which threaten to marginalize entire populations still living in dire poverty. 
RK: What then do you see as the solution for overcoming such global problems?

AW: I am convinced, and I have never received any disagreement over this, that the ultimate answer resides in education. That is, if we are to successfully confront the massive developmental problems that beset the developing world, we must, in my opinion, transform the perception that the globalization process works only for the rich and powerful and is largely irrelevant for the great masses of the world. To bring about such a transformation, greater priority must be placed on the critical role that education plays in national development. The benefits of sound planning and investment in education can readily be seen in the success stories of the "Four Tigers" of Asia, namely: Hong Kong, Taiwan, South Korea, and Singapore. In all these countries, the common feature before industrial "take off" was access to a high quality primary education. A second important feature shared by the Four Tigers was the need to ensure that higher levels of education systems were in place on time. That is, as the expansion of primary education took place, the focus shifted to the expansion of secondary education and eventually to the tertiary level. In short, the process of national development is intimately intertwined with the quality and level of education in the respective societies.

RK: From your experience, can you reflect on some of the principles that a good international program or an international educator should be attuned to?

AW: Let me try to illustrate what I believe would be some worthy principles of international work by using two agricultural development projects which I was asked to evaluate some years ago. I leave it to the reader to make the appropriate connections to the educational context. Both Projects took place in South East Asia and both involved Canadian funding. The smaller of the two projects involved two ideas that villagers held to develop their community. One was to bring under cultivation a small, fertile island located in a nearby river by planting cocoa as the long-term cash crop under the shade of tall kapok trees to protect the tender cocoa plants. The idea came solely from 
members of the village who were directly involved in the planning, development, and implementation stages of the project. The funding agency's main involvement was to provide the necessary agricultural training with respect to cocoa production. That is, Canada's role was to supply the needed human resources and technical assistance as determined by the elected Village Committee. The second project of the villagers involved sheep farming on nearby available land. External funding was used to import sheep from Australia which were adapted to the tropical heat and to provide agricultural expertise on animal husbandry to the villagers as requested. Both these village projects were small in scale, involved a high level of direct involvement, and reflected a high sense of ownership (and I think pride) by the local community members. The prevalent attitude behind both endeavors of the villagers was to provide them with the necessary skills (and where necessary, limited human resources) and they will take responsibility for the rest. If you like, don't give us the fish, rather teach us how to fish.

The other project I was asked to evaluate was much larger and had a higher profile, at least internationally. It involves the clearing of a large area (about 700 acres) in order to grow rice on a commercial scale using modern technology and techniques. Canada was only one of many international funding agencies involved in the scheme, which displaced some 550 families, involving over 2000 individuals. The project proved highly effective and productive in the sense that five rice crops were now able to be harvested every two years and the displaced family members received over twice the income they had made prior to the project, when they cultivated their smaller, individual (i.e. less productive) peasant farms. Yet, only about $6 \%$ of the original farmers were employed on this new rice paddy development and a great deal of effort was made to try to find appropriate employment for the several hundred individuals who were unemployed as a result of the introduction of "western technology'. In my evaluation, I was hard pressed to even distinguish which part of the rice development scheme belonged to Canada! The many efforts to engage the displaced farmers in alternate sources of income (small tea shops, machine/bicycle repair shops, noodle factory, small stores, tailor shops, etc) were largely ineffective and proved non-viable even in the short 
term for the majority of those displaced. However, visitors to the site lauded the project as a highly successful international development project, complete with huge signs listing the various agencies involved. Many seemed impressed by the electronic bird scarers, the automated irrigation system, use of bulk fertilizers, and mechanical harvesters like you might expect to see in western Canada. Few if any visitors were taken to see the human devastation the project had on the several hundred individuals whose self-worth and way of life were largely destroyed as a consequence, to say nothing of the sustainability of the venture in the longer term. Which project (the small scale village cocoa/sheep project or the commercial production of rice), would you assign the better grade to?

I would like to think that such examples of poorly designed development projects in any sector, where those most directly involved are excluded from direct participation, decision making, and ownership in the process, are rare these days. I believe that we, as Canadians, have learned much over the years about effective international contribution and sound development principles and can do much to foster national development in countries far less fortunate than our own.

RK: In this day and age of limited resources, many institutions including Brock University, increasingly look to international programs to off-set funding short-falls? Do you see ethical problems with such initiatives?

AW: Your question reflects both good news and bad news. There is no doubt that we are more engaged in the process of fostering internationalization at Brock in recent years than we ever have been. Currently, for example, we are close to achieving the university goal of having $10 \%$ of the student population on campus being international students, which represents a significant increase over the last decade. This is obviously good news, but there is also a need to examine more closely how this internationalization process can become more fully operational in a generic sense across the institution. Ethically, I would have more concern if we become overly reliant on international "costrecovery" initiatives in education which serve in some ways to 
subsidize regular offerings. We should attempt to introduce all students to an international perspective throughout their academic and social experiences by establishing an ethos or culture in all programs that values both intercultural and international perspectives. I am encouraged to the extent that we have made real advances in this direction. Recent efforts in the Faculty of Education to Infuse Global Notions in Teacher Education or I.G.N.I.T.E. provide an example of how internationalization is being translated for implementation at the classroom level. As countries around the world move into an era of global integration, citizenship can no longer be defined by national boundaries. For this reason, it is increasingly important that we learn to see ourselves - and those we educate as prospective teachers to see themselves - as responsible global citizens. By infusing such an ethos in our Teacher Education candidates, we help to ensure that, through their influence as future educators, young Canadians in their classrooms will become more informed about and engaged in global issues. It is through such efforts that Canada's international efforts can be furthered.

RK: Administratively, what resources are needed in order to see that such initiatives come to fruition and do not fizzle?

AW: The financial resources allotted for infusion of global notions into the teacher education curriculum are minimal as they build on what some are already doing and therefore should only add additional workload. What is required, which is much more difficult to achieve, is a shift in attitude of educators to deal meaningfully with international issues and global examples in their teaching and generally applying global thinking as a constant filter in all their actions. The real challenge is to bring about such a mind set.

RK: How do you feel Canada, which has been characterized as a "middle-power" nation, fairs on the international educational scene?

AW: I feel we could do much more on the global educational scene than we have been doing. My experience has been that we, as Canadians, are well regarded on the global stage, but have yet to truly 
exercise our global voice. We have the capacity to make a significant contribution, but are often conspicuously absent in our actions.

The aftermath and turmoil of the terrorist attacks of $9 / 11$ has reflected our inward-looking side more than I would have liked and our global influence has waned considerably in recent years. This is unfortunate, as there was a time when Canada had a strong international voice with considerable moral authority. Consider, for example, what has happened to Canada's foreign aid allocation in recent years. The agreed-upon international benchmark of $0.7 \%$ of Gross National Product, established incidentally by Canada, reached a high mark of $0.49 \%$ in 1992 and now is holding around $0.30 \%$. Since 1995, when Canada ranked sixth out of the world's 22 richest countries for foreign assistance, it has tumbled to seventeenth place. The need for Canada to step up its assistance to others less fortunate is still acute. Despite a global rise in living standards over the past decade, there are still 1.3 billion people who subsist on $\$ 1$ a day or less. Further, more than 27,000 children under the age of five die, most from preventable diseases such as measles, diarrhoea, and respiratory infection. Surely it is our moral obligation to help as Stephen Lewis, the eloquent UN AIDS Envoy, continually reminds us.

RK: What role would you like Canada to play on the world stage?

AW: Your framing of the question might best be answered using a theatrical metaphor. Should Canada assume a major role globally or are we to merely remain a minor player with an insignificant role? Like theatre itself, Canada's global role should have a distinct purpose. That is, it should illuminate and instruct, and be capable of bringing about social readjustments, not only in individuals and communities but even across countries. We must, as Canadians, translate the time-tested adage, "Think Globally, Act Locally" as a national policy into concrete action.

To come back to the stage metaphor, I would suggest that our role as a nation on the global stage should be akin to our national character. Certainly not the lead player or the overall star of the performance, but one who is capable of stealing the show for a wellrehearsed, well-thought-out, sincere, and distinctive performance. My 
hope would be that with our proven multicultural script and experience, we could receive an Oscar Award for the Best Supporting Actor on the global stage, a role that would demonstrate through concrete action, that it is possible to make a global difference.

RK: Finally, as you will be retiring shortly, what international adventures do you and Hilde have planned for the future?

AW: Again, I would like respond to your question indirectly by quoting from a poem called the Challenge found during the excavation of the ancient Indus civilization city of Moenjodaro (in present day Pakistan) which dates back to at least 2500 years B.C. The original poem is very long but I believe the following verse best captures our hope for life after Brock and how challenges may unfold for Hilde and me in the future. Hopefully it will involve new cultural explorations and challenges with continued efforts to internationalize education.

Surgite!

\section{The Challenge}

Listen to the exhortation of the dawn!

Look to this day!

For it is life, the very life of life.

In its brief course lie all the verities and realities of your existence;

The glory of action, the bliss of growth, the splendor of beauty.

For yesterday is but a dream,

And tomorrow is only a vision;

But today, well lived, makes every yesterday a dream of happiness

and every tomorrow a vision of hope.

Look well, therefore, to this day!

Such is the salutation of the dawn.

(Ancient Sanskrit Poem, Moenjodaro) 